\title{
Is Religious Intolerance Good for Your Health?
}

\section{Reflections on Korea and covID-19}

\author{
Ciarán Burke \\ Professor and Senior Research Fellow, Jena Center for Reconciliation Studies, \\ Friedrich Schiller Universität, Jena, Germany \\ Ciaran.Burke@eui.eu
}

\begin{abstract}
Legal responses to the COVID-19 pandemic have varied widely. Korea represents an interesting case study, as it seemed particularly well prepared, having enacted legislation in the wake of the MERS outbreak, in 2015, to tackle future pandemics. This obviated recourse to emergency powers legislation, and couched Korea's response in normal legislation, which tends to raise fewer human rights concerns than may arise under emergency measures. Despite this, however, Korea's response to CoviD-19 raises significant questions about its compliance with core human rights norms under the International Convention on Civil and Political Rights, including freedom of religion and non-discrimination. These arose with regard to the state's treatmennt of members of the Shincheonji Church of Jesus (SCJ), a relatively small, occasionally controversial, religious group. The treatment of the SCJ by the Korean state raises questions about whether its legal approach to tackling COVID-19 was fit for purpose.
\end{abstract}

\section{Keywords}

emergency powers - non-discrimination - human rights - proportionality international law - Korea - coviD-19 
The CoviD-19 crisis is the result of a global pandemic, having spread to virtually all corners of the globe ${ }^{1}$ a potentially mortal threat experienced by all states simultaneously. The crisis has affected societies in different countries in a variety of manners, and the responses crafted by state leaders have been far from uniform. Some governments, such as that of Australia, have been clear that the outbreak warrants the declaration of a state of emergency, ${ }^{2}$ whereas others, for example, in Bangladesh, have acted in a more ad hoc manner, declaring a country-wide "general holiday" instead of an official lockdown, with repeated prolongation of the measures undertaken. ${ }^{3}$ Japan declared a state of emergency, but relied on voluntary social distancing (jishuku), ${ }^{4}$ rather than legal means for its enforcement. Other countries, such as Brazil and Hungary, have avoided explicitly declaring an emergency, employing the crisis as an excuse for exercising extraordinary powers and implementing legislation aimed at curtailing civil liberties and aggregating additional authority to the executive branch. ${ }^{5}$

The virus itself therefore does not represent the sole danger. A further peril may emanate from the abuse of emergency powers or other responses designed to deal with a developing crisis. ${ }^{6}$ Situations of grave national crisis have, in the past, been used to enact extraordinary legal measures in the name of national security, public health, or for a number of other reasons. ${ }^{7}$ Such measures, however, may be intended to achieve other goals, such as "curtailing

1 At the time of writing, a few isolated countries, such as Nauru, Kiribati, and the Solomon Islands had yet to report cases of the virus, as had Antarctica.

2 In Australia, the state of emergency has been extended in Victoria and other states. See, for example, The Premier of Victoria. "State Of Emergency For Coronavirus Extended To Save Lives" Retrieved 12 August 2020, https://www.premier.vic.gov.au/state-of-emergency-for-corona virus-extended-to-save-lives/.

3 Mustafizur Rahman. "Bangladesh govt extends general holiday till May 30". NewAge Bangladesh, 12 August 2020. Retrieved https://www.newagebd.net/article/106397/bangladesh-govt -extends-general-holiday-till-may-30.

4 Makoto Nishi. "Jishuku, social distancing and care in the time of covid-19 in Japan". Social Anthropology, 18 May 2020.

5 See Renáta Uitz. "Pandemic as Constitutional Moment: Hungarian Government Seeks Unlimited Powers." Verfassungsblog, 24 March 2020. See also Emilio P. Neder Meyer \& Thomas Bustamante. Authoritarianism Without Emergency Powers: Brazil Under covid-19. Verfassungsblog, 8 April 2020.

6 See John Ferejohn \& Pasquale Paquino. "The law of the exception: A typology of emergency powers", 2(4) I-CON (2004), 210-239.

7 See Myriam Feinberg. "International Counterterrorism - National Security and Human Rights: Conflicts of Norms or Checks and Balances?", in M. Feinberg, L. Niada-Avshalom, and 
dissent, dissolving Parliament, postponing elections or aggregating additional powers to the executive." 8 When the crisis is over, some approaches employed are likely to prove problematic when it comes to complying with human rights norms. The measures deployed around the globe have significant consequences for the universal protection of human rights. Although the evolving crisis is unique, and has caught the international community of states somewhat unprepared, international law still has something to say about the various choices made by national governments to cope with the crisis. International human rights law provides a universal framework to guide decision makers, which ensures accountability for their choices and provides a useful lens through which the differential effect of the various strategies employed may be viewed. ${ }^{9}$

This article examines one of the few cases involving a state that was relatively well prepared for the crisis. The Republic of Korea (hereinafter, Korea) had learned significant lessons from the Middle East Respiratory Syndrome (MERS) outbreak in $2015 .^{10}$ The Korean government was quick to identify the importance of preventive measures, early diagnostics, and a centralized control system to fight infectious diseases." ${ }^{11}$ It identified problems with the relevant legislation in force and implemented significant reforms, obviating the necessity to declare a state of emergency. ${ }^{12}$ The framework has helped Korea manage the CoviD-19 outbreak with greater success than many other countries. ${ }^{13}$ Yet, the Korean tackling of the crisis has not been without controversy. A significant proportion of confirmed cases were publicly attributed by officials to contacts with a controversial religious congregation, and the dealings of the authorities with members of this church raise questions about compliance with several human rights, not least of them freedom of religion, freedom of assembly, freedom of association, and the right to privacy.

B. Toebes (eds), National Security, Public Health: Exceptions to Human Rights? (Routledge, 2016), 388-407.

8 Martin Scheinin. “CoviD-19 Symposium: To Derogate or Not to Derogate?" OpinioJuris, 6 April 2020.

9 See Ernst-Ulrich Petersmann. "Human Rights, International Economic Law and 'Constitutional Justice", 19(4) European Journal of International Law (2008), 769-798.

10 Sang-il Lee. "Costly Lessons From the 2015 Middle East Respiratory Syndrome Coronavirus Outbreak in Korea”, 48(6) Journal of Preventive Medicine \& Public Health (2015), 274-276.

11 Seung-Youn Oh. “South Korea's Success Against covid-19”. The Regulatory Review, 14 May 2020.

12 Brian Kim. "Lessons for America: How South Korean Authorities Used Law to Fight the Coronavirus". Lawfare, 16 March 2020.

13 Edward White. "South Korea reports no new local coronavirus cases." Financial Times, 30 April 2020. Retrieved 12 August 2020, https://www.ft.com/content/a92aeefa-a4ea-424b -b8a5-fa13eo15b5d5. 
This article offers an overview of the Korean response to coronavirus to date (July 2020). The account begins with a survey of the Korean reforms undertaken in the wake of the 2015 MERS crisis, including the legislative framework. Next, it describes the CoviD-19 outbreak in 2020 and how the reformed legal apparatus was put in action to respond to the crisis. The peculiar circumstances of the outbreak in Korea are explained, with an account of how they made responding to the crisis more difficult than it may otherwise have been. The article concludes with an assessment of compliance by Korea with its human rights obligations under the International Convention on Civil and Political Rights (ICCPR) and some observations concerning the actions of agents of public power, at both national and regional level.

The MERS Outbreak in 2015 and Lessons Learned

Korea reported its first confirmed case of MERS on May 20, 2015. After the case was confirmed, Korean public healthcare authorities enforced several preventive and ex post measures for the protection of public health, which were not authorized under Korean law. ${ }^{14}$ The legislation dealing with infectious diseases that was in force at the time did not grant effective enforcement powers for mass public health measures to either the central or the regional authorities. ${ }^{15}$

The initial response to the MERS outbreak was characterized by secrecy on the part of the government. The Korean Ministry of Health withheld details concerning the locations of infected individuals from the public, on the grounds that identifying the medical institution treating MERs patients might cause unnecessary anxiety to other patients, rather than out of concern for the privacy of those infected. ${ }^{16}$ This approach failed to garner public acceptance, and was criticized as preventing the Ministry from properly notifying hospitals and municipal governments about risks they might face. In early June

14 Dohyeong Kim. "Public Health Crisis in South Korea: Policy Failure or Social Trust", in Korean Cases in Public Administration for Training and Practice (Daeyoung Moonhwasa Publishing Co., 2017).

15 Mijeong Park. Infectious disease-related laws: prevention and control measures, Epidemiology and Health, Vol. 39:e2017033 (July 2017).

16 Shin, Ji-hye. Korea mulling disclosure of MERS-affected hospitals, Korea Herald (2 June 2015); Lim Poh Lian. "Middle East respiratory syndrome (MERs) in Asia: lessons gleaned from the South Korean outbreak", 109(9) Transactions of The Royal Society of Tropical Medicine and Hygiene (2015), 541-542; Bae, Jong-Myon. 'The Duty to Prevent' during an epidemic situation like 2015 Korean MERS outbreak", 37 Epidemiology and health (2015), e2015037-e2015037. 
2015, the secrecy delayed the epidemiological response, when a doctor who had developed symptoms of MERS and later tested positive, attended a large public gathering. Despite the initial proposal by the Ministry to engage in "passive surveillance" only, municipal authorities managed to obtain a list of those present at the gathering and contacted them directly. Eventually, the Ministry disclosed the names of the medical institutions that had been exposed to MERS. ${ }^{17}$

Although the MERS crisis lasted only for a few months, several important lessons had been learned. ${ }^{18}$ One crucial issue identified was the need for interinstitutional cooperation. Before the outbreak, various state agencies and government organs disposed of overlapping competences, often hindering the coordination of national efforts. It was determined that this required rectification, and that a new legal regime for the management of infectious disease outbreaks should be implemented. This consisted chiefly of provisions contained in the Infectious Disease Control and Prevention Act (IDCPA), which came into force in 2016. ${ }^{19}$ Although many of the provisions of the IDCPA seemed prima facie innocuous and prudent in light of the MERS outbreak, others were to prove more controversial. For example, Article $76-2$ IDCPA grants the Ministry of Health and the Director of the Korean Center for Disease Control (KCDC) extensive legal authority to collect personal data, without a warrant, from those already infected and from potential patients. Article 76-2(1) enables the authorities to require "medical institutions, pharmacies, corporations, organizations, and individuals" to provide "information concerning patients... and persons likely to be infected." Article $76-2(4)$ also expressly mandates private telecommunications companies, as well as the National Police Agency to share the "location information of patients... and [of] persons likely to be infected" with health authorities, upon request. The potential ramifications of the legislation were significant, particularly in the absence of a list of relevant factors for identifying persons "likely to be infected" through contact tracing. This raised the possibility of large lists of individuals being drawn up based upon criteria devised by state officials, rather than legal professionals, and personal data being surrendered to central governmental authorities. Public and private authorities, upon request, were obligated to surrender, among others: (a) personal information, such as names, resident registration numbers, addresses,

17 Gerardo Chowell et al. "Transmission characteristics of MERS and SARS in the healthcare setting: a comparative study." 13(1) BMC medicine (2015), 210.

18 Changhwan Leeand Moran Ki. "Strengthening epidemiologic investigation of infectious diseases in Korea: lessons from the Middle East Respiratory Syndrome outbreak", 58(8) Journal of the Korean Medical Association (2015), 706.

19 Act No. 13639, revised on December 29, 2015, and effective since June 30, 2016. 
and telephone numbers; (b) prescriptions and records of medical treatment; (c) records of immigration control; and (d) other information for monitoring the movement of patients with infectious diseases. Referring to "other information," the content of which may be determined by future presidential decrees, makes the ambit of the material that may be suggested by the authorities potentially quite broad. The sole requirement under Korean data protection law is that the individuals be notified that they have been placed under surveillance, and that such information should be destroyed when the "relevant tasks have been completed," but the means by which such information can be effectively destroyed is not prescribed.

Finally, attached to the provisions of Article 76 are several subsections of Articles 6 and 34(2), which expand the ability of the public to access information regarding infectious patients. Articles 6 and 34(2) invokes the public "right to know," requiring the Ministry of Health to "promptly disclose information" to the public about the "movement paths, transportation means... [and] contacts of patients of the infectious disease." Creation of a public right to know and an obligation incumbent upon state authorities to share information with the public concerning infected individuals represents another significant incursion into the private lives of infected persons and of those with whom they had contact. ${ }^{20}$ The legislation also granted the government a variety of legal tools for imposing physical restrictions during a health crisis. Article 47(1) empowers authorities to shut down any location "recognized (or confirmed) to have been infected," without stipulating any test for contamination. Article $49(1)(2)$ further permits the "restrict[ion] or prohibit[ion of] performances, assemblies, religious ceremonies, or any other large gathering of people."

This approach, based on data sharing, transparency, and the prioritization of public health, represented the antithesis of the secretive, uncoordinated response model that preceded the MERS outbreak, This framework, however, raised serious questions concerning privacy and risk of abuse, as it became clear during the CoviD-19 pandemic.

\section{3} Circumstances of the covid-19 Outbreak

The CoviD-19 pandemic spread to Korea in the early weeks of 2020. The first case was announced on January 20. By February 17, only 30 individuals had

20 Eun A. Jo. "South Korea's Experiment in Pandemic Surveillance", The Diplomat, 13 April 2020. Retrieved 12 August 2020, https://thediplomat.com/2020/04/south-koreas-experiment-in -pandemic-surveillance/. 
been confirmed as infected. Having dealt with previous epidemics, the government seemed prepared, and appeared confident in its ability to contain the virus, owing in part to the aforementioned legal and bureaucratic reforms, as well as to state-of-the-art technology. Preparations for management of a fresh epidemic began as early as November 2019, before an official case in China had even been announced, ${ }^{21}$ In mid-February, President Moon declared that he was confident that "the situation [would] almost disappear,"22 and urged people not to succumb to "excessive fear and anxiety [that would make] it more difficult for the economy."23 The government banned foreign nationals from Hubei Province, China, from entering Korea on March 19, 2020. ${ }^{24}$

The situation changed markedly on February 16, 2020, when a 61-year-old woman, who has since become known as Patient 31, entered a building belonging to the Shincheonji Church of Jesus (SCJ) in the southern city of Daegu. To enter the building, she had to touch her finger on a digital fingerprint scanner. She went downstairs into a prayer hall, where she joined a ceremony with approximately 1,00o other worshippers in a windowless room. After several hours, she exited, apparently having left a trail of pathogens behind, which was identified by the Korean authorities as having triggered one of the largest COVID-19 outbreaks in the world. ${ }^{25}$

The SCJ is a relatively small Christian sect with approximately 320,000 members. ${ }^{26}$ It is part of the so-called Christian new religious movement,

21 Christopher Khatouki. "Clandestine Cults and Cynical Politics: How South Korea Became the New Coronavirus Epicentre”, The Diplomat, 12 March 2020. Retrieved 12 August 2020, https://thediplomat.com/2020/03/clandestine-cults-and-cynical-politics-how-south-ko rea-became-the-new-coronavirus-epicenter/.

22 Christopher Khatouki. "Clandestine Cults and Cynical Politics: How South Korea Became the New Coronavirus Epicentre”, The Diplomat, 12 March 2020. Retrieved 12 August 2020, https://thediplomat.com/2020/o3/clandestine-cults-and-cynical-politics-how-south-ko rea-became-the-new-coronavirus-epicenter/.

23 Do Je-hae. "Moon orders emergency economic policy", The Korea Times, 18 February 2020. Retrieved 12 August 2020, https://www.koreatimes.co.kr/www/nation/2020/02/356 _283679.html.

24 See Central Disaster Management Headquarters. "Korean government's response system". Retrieved 12 August 2020, http://ncov.mohw.go.kr/en/baroView.do?brdId=11\&brdGubun $=111 \&$ dataGubun $=\&$ ncvContSeq=\&contSeq=\&board_id=\&gubun=>.

25 Derek Thompson. “What's Behind south Korea's covid-19 Exceptionalism”, The Atlantic, 6 May 2020. Retrieved 12 August 2020, https://www.theatlantic.com/ideas/archive/2020/05/ whats-south-koreas-secret/611215/.

26 In South Korea, the largest individual group of those members of the population espousing a religion (44\% of 51.6 million inhabitants) are Protestant (19.8\%). Buddhism and Roman Catholicism are two other important religions. Followers of other religions, including Confucianism, Cheondoism, and others, represent around $2 \%$ of the religious 
constituting several relatively new church groups in Korea. New religions are especially popular in Korea, with Christian new religious movements gaining prominence after the end of the Korean War. ${ }^{27}$ Other congregations within this group, however, have larger membership bases, such as the Unification Movement, with between 1 and 2 million members, and the Yoido Full Gospel Church, with around 500,000 members. ${ }^{28}$ Of the 50 largest churches in the world, around 23 are in Korea. ${ }^{29}$ The SCJ enjoys a disproportionately high profile in Korea, and is unpopular with members of other religious congregations and with certain sections of the general public. ${ }^{30}$ In particular, the larger protestant congregations have spread social hostility against the $\mathrm{SCJ}$, which they see as an upstart movement with heretical views. ${ }^{31}$

The devout practices of SCJ members have occasionally caused controversy in Korea and abroad. The Church, founded in 1984, is divided into Twelve Tribes, each with a Tribe leader, overseeing 71 churches in Korea and 57 overseas. $^{32}$ SCJ teachings are based on the Bible, which contains "prophecies... expressed through parables" that announce promised future events and can be physically fulfilled..$^{33}$ To become a member of the Church, one must complete a Bible study course. ${ }^{34}$ The Church attracts many young people, including university students, who often join its ranks from other Protestant churches. Because of its rapid growth at the expense of fundamentalist Protestant churches,

population. The SCJ belongs to the Protestant branch, alongside Jehovah's Witnesses, Sabbathism, Mormonism, the Anglican Church, Unificationism, and others. See Kosıs's statistics updated on May 1, 2017. Retrieved 12 August 2020, http://kosis.kr/statHtml/statHt ml.do?orgId=101\&tblId=DT_PM1502\&conn_path=I2; U.S. Department of State. International Religious Freedom Reports. South Korea. Retrieved 12 August 2020, https://www .state.gov/report/custom/52af4ebd57-2/.

27 Lukas Pokorny. “Korean New Religious Movements: An Introduction", in Lukas Pokorny \& Franz Winter (eds), Handbook of East Asian New Religious Movements (Brill, 2018), 243-244.

28 See Eileen Barker. "The Unification Church", 9(1) Alternative Spirituality and Religion Review. Special Issue on Korean New Religions (2018), 91-105.

29 Sebastain C. H. Kim. "Mega Churches in South Korea: Their Impact and Prospect in the Public Sphere", in J. D. James (ed.), A Moving Faith: Mega Churches Go South (sAG E Publications, 2015), 85-105.

30 International Institute for Religious Freedom. "COVID-19 cannot be an excuse to demonise and stigmatise a religious minority", 15 April 2020. Retrieved 12 August 2020, https://www .iirf.eu/news/other-news/covid-19-cannot-be-an-excuse-to-demonise-and-stigmatise-a -religious-minority/.

31 Massimo Introvigne. "Shincheonji: An Introduction", 4(3) The Journal of CESNUR (2020), 13 .

32 Ibid., 14.

33 Ibid., 9 .

34 Ibid., 13. 
the Church was often derogatively labelled by other denominations. ${ }^{35}$ In response, the SCJ defended its position through recruitment and information campaigns, and a culture of increasing secrecy. The practices have raised concerns that those who join the SCJ are deceived into joining it and that the SCJ is engendering religious competition. ${ }^{36}$

Like other Protestant churches, the SCJ has a central figure, Chairman Lee, who is believed to guide the Church into the millennium-a future without sickness and death. ${ }^{37}$ As in other Christian teachings, the Church links sickness to individual sins, although not all ailing is caused by sin, and avoiding sins does not necessarily render an individual invulnerable to illness. Followers of the SCJ pray twice weekly and kneel during the service, similarly to Muslims. As with other churches in Korea, worship usually takes place in large multi-use buildings, partly because securing bespoke premises for worship (such as cathedrals, mosques, et cetera) is often problematic. ${ }^{38}$ In times of crisis, even the most innocuous religious practices, such as sitting on the floor during service or praying for those who are sick, may seem odd. ${ }^{39}$ Yet, "theological criticism should not be confused with discrimination or violation of human rights." 40

The SCJ claims that well before Patient 31 was infected and identified, it informed its members about the risk of infection and took preventive measures. In January and February, the SCJ made several rounds of announcements to their followers regarding these measures, including being vigilant for symptoms, observing basic hygienic and epidemiological requirements, such as hand washing and self-quarantine, as well as travel advice, in particular with respect to China, although there are no $\mathrm{SCJ}$ gatherings in China. Moreover, persons identified as being at risk of infection were prohibited from entering church premises from the beginning of February. Despite the warnings, Patient 31 attended several large-scale church gatherings and is assumed to have spread the disease to hundreds of churchgoers. ${ }^{41}$ By February 20, 53 new cases had either attended the SCJ ceremony in Daegu or were family members of those who had done so. The figure exceeded 300 by February 23, constituting

\footnotetext{
35 Ibid., 14.

$36 \quad$ Ibid., 15 .

$37 \quad$ Ibid., 11-12.

$38 \quad$ Ibid., 12.

39 Massimo Introvigne et al. Shincheonji and Coronavirus in South Korea: Sorting Fact from Fiction, (Human Rights Without Frontiers, white paper, 2020), 12.

$40 \quad$ Ibid.

41 Christopher Khatouki. "Clandestine Cults and Cynical Politics: How South Korea Became the New Coronavirus Epicentre", The Diplomat, 12 March 2020. Retrieved 12 August 2020, https://thediplomat.com/2020/o3/clandestine-cults-and-cynical-politics-how-south-ko rea-became-the-new-coronavirus-epicenter/.
} 
over half of all cases in Korea. ${ }^{42}$ There was almost no spread of the virus between members outside of Daegu. By March 8, the KCDC announced that $79.4 \%$ of confirmed COVID-19 cases were related to group infections. The KCDC further noted that that outbreak associated with SCJ totaled 4,482 infections, accounting for $62.8 \%$ of the confirmed cases in the country. ${ }^{43}$ As of July 21 , the proportion of the total cases associated with the SCJ had dropped to $37 \%{ }^{44}$ As the number of cases in Korea rose, the origin of the cases became more diversified, with a progressively lower proportion being linked to the SCJ. ${ }^{45}$

On February 19, President Moon called for a full survey and examination of all members of SCJ, whether or not they were likely to have had contact with Patient $31 .{ }^{46}$ The Prime Minister instructed the KCDC to tests the entire SCJ community. ${ }^{47} \mathrm{He}$ vowed that all members of the Church would be "found and tested," his language contributing to the impression that the Church was attempting to conceal its membership. ${ }^{48}$ The central administration quickly proceeded to test and interview all members of the SCJ, regardless of whether there was evidence that they had come into contact with the virus, a policy that was not applied to other groups.

As soon as Patient 31 was identified, the SCJ formed a COVID-19 Task Force at its headquarters. On February 21, the SCJ disinfected all its facilities. The next day, it handed over the list of all its facilities to the KCDC, and requested cooperation in the prompt identification of all infected SCJ members. On February 25, the SCJ provided the Korean authorities, upon request and after some negotiation, with a list of more than 240,000 members, demanding that their identities be protected. This was acknowledged by Deputy Minister of Health, Kim Kang-lip, who publicly stated that the SCJ had cooperated with

42 "Coronavirus Live Updates: Xi Acknowledges 'Shortcomings' in Fight Against Outbreak", The New York Times, 23 February 2020. Retrieved 12 August 2020, https://www.nytimes .com/2020/02/23/world/asia/china-coronavirus.html.

43 Bahk Eun-ji. "New cases of infections drop for third day", The Korea Times, 9 March 2020. Retrieved 12 August 2020, https://m.koreatimes.co.kr/pages/article.asp?newsIdx=285870.

44 KoreanCentreforDiseaseControl. "TheupdatesoncoviD-19inKoreaas of 21July",Retrieved 12 August 2020, https://www.cdc.go.kr/board/board.es?mid=a30402000000\&bid=0030.

45 Yun-Jung Kang. "Characteristics of the covid-19 Outbreak in Korea From the Mass Infection Perspective", 53Journal of Preventive Medicine \& Public Health (2020), 168-170.

46 Choi He-suk. "Moon calls for inspection of Shincheonji Church of Jesus in relation to Covid-19", The Korea Herald, 21 February 2020. Retrieved 12 August 2020, http://www.ko reaherald.com/view.php?ud=20200221000547. "(3rd LD) PM calls for extraordinary measures to contain virus", Yonhap News Agency, 11 February2020.Retrieved12 August2020,https://en.yna.co.kr/view/AEN20200225006153315.

48 Kim, So-hyun. "Shincheonji didn't lie about membership figures", The Korea Herald, 17 March 2020. Retrieved 12 August 2020, http://www.koreaherald.com/view.php?ud=2020 0317000667. 
the authorities. ${ }^{49}$ The statement strongly contrasts with contemporaneous media accounts, which cited withholding information and a culture of secrecy as thwarting the efforts of public health authorities. ${ }^{50}$ By March 2, the government was able to identify 3,917 confirmed cases on the basis of the list provided. ${ }^{51}$ On March 3, Lee Man-hee, head of the SCJ, publicly apologized for the role of the Church in the epidemic and called for an end to "stigmatization, hatred and slander" of its followers. ${ }^{52}$

The connection between the SCJ and the COVID-19 outbreak provided ammunition for those opposed to the growth of the Church and those who saw new religions as a threat. SCJ was repeatedly cited in the media as having impeded government requests for transparency concerning its membership, of having provided false lists of members, and of having asked members to hide from the authorities. ${ }^{53} \mathrm{SCJ}$ members were allegedly instructed not to wear face masks, as their belief would protect them from the virus. Certain individuals were allegedly told to endure COVID-19 and attend church services despite the pandemic, or even to inject themselves with the virus. ${ }^{54}$ These allegations were amplified by official actions at several levels. The KCDC issued repeated press releases explicitly linking the $\mathrm{SCJ}$ to the outbreak in statistical terms, contributing to a sense of public paranoia directed at what was already a marginalized and unpopular religious community. Patient 31 was often referred to as a "superspreader." KCDC epidemiological tables clearly differentiated the SCJ from other churches that experienced outbreaks of infections, with the SCJ cluster singled out from other large clusters, even when the numbers linked to the latter exceeded new infections linked to the SCJ. ${ }^{55}$ The KCDC called

49 Ministry of Health. "Press Release". Retrieved 12 August 2020, https://www.mohw.go.kr/ eng/nw/nwo101ls.jsp?PAR_MENU_ID=1007\&MENU_ID=100701

5o Raphael Rachid. "Being Called a Cult Is One Thing, Being Blamed for an Epidemic Is Quite Another", New York Times, 9 March 2020. Retrieved 12 August 2020, https://www.nytimes .com/2020/03/og/opinion/coronavirus-south-korea-church.html.

51 Yun-Jung Kang. "Characteristics of the covid-19 Outbreak in Korea From the Mass Infection Perspective", 53Journal of Preventive Medicine \& Public Health (2020), 168-170.

52 Hyonhee Shin \& Ju-min Park. "Founder of South Korea church at center of virus outbreak regrets 'great calamity", Reuters, 2 March 2020. Retrieved 12 August 2020, https://www .reuters.com/article/us-health-coronavirus-southkorea-toll/founder-of-south-korea -church-at-center-of-virus-outbreak-regrets-great-calamity-idUSKBN20Po5K.

53 Christopher Khatouki. "Clandestine Cults and Cynical Politics: How South Korea Became the New Coronavirus Epicentre”, The Diplomat, 12 March 2020. Retrieved 12 August 2020, https://thediplomat.com/2020/o3/clandestine-cults-and-cynical-politics-how-south-ko rea-became-the-new-coronavirus-epicenter/.

54 Ibid.

55 Korean Centre for Disease Control. "The updates on Covid-19 in Korea as of 6 July". Retrieved 12 August 2020, https://www.cdc.go.kr/board/board.es?mid=\&bid=0030\&act $=$ view\&list_no $=367718 \&$ tag $=\&$ nPage $=1$. 
the SCJ a cult (sect) in an official report that led world news to employ the same, often misunderstood and labelling, terminology. Such labels are difficult to escape, reflecting the concern raised by the wHO that "it is very important that we do not profile the cases on the basis of racial, religious and ethnic lines." 56

In early March, Seoul Mayor, Park Won-soon, announced a lawsuit against 12 scJ leaders "for murder, injury, and violation of prevention and management of infectious diseases"57 "through willful negligence. ${ }^{n 8} \mathrm{He}$ also threatened to revoke the license of the SCJ to operate. The central government moved quickly to close SCJ facilities and buildings. ${ }^{59}$ Media agencies placed the SCJ under significant scrutiny, sensationalizing the coverage and noting, for example, that Patient $3_{1}$ remained in the hospital for $5^{8}$ days, with the single room she occupied costing 400,000 won per day and the total hospital bill exceeding 40 million won. ${ }^{60}$ In late February, a petition to President Moon urging the disbandment of the SCJ attracted over 750,000 signatures, most of them from fundamental Christian groups. ${ }^{61}$ In response, the Korean Government admitted that it was not within its powers to ban a Church, but the National Tax Service immediately started investigating the SCJ. ${ }^{62}$ On February 25, SCJ headquarters in Gwacheon, Gyeonggi Province, was raided by law enforcement officers, and government officials announced that all members of the religious group would

56 DTE Stuff. "Refrain from religious profiling of coviD-19 cases: wHO in context of Tabligh", Down To Earth, 7 April 2020. Retrieved 12 August 2020, https://www.downtoearth .org.in/news/health/refrain-from-religious-profiling-of-covid-19-cases-who-in-context -of-tabligh-70262.

57 Rhea Mahbubani. "The leader of a fringe religious sect at the center of South Korea's coronavirus outbreak has apologized as Seoul's mayor files lawsuit accusing the group of 'murder' and 'injury", Business Insider, 2 March 2020. Retrieved 12 August 2020, https://www .businessinsider.com/south-korea-seoul-mayor-sues-shincheonji-coronavirus-outbreak -leader-apologizes-2020-3?r=DE\&IR=T.

58 Choe Sang-Hun. “He Blames 'Evil' for South Korea's Coronavirus Surge. Officials Blame Him", New York Times, 2 March 2020. Retrieved 12 August 2020, https://www.nytimes .com/2020/03/o2/world/asia/coronavirus-south-korea-shincheonji.html.

$59 \quad$ Ibid.

$60 \quad$ 홍완기. “31번확진자입 원 ‘ 58 일 째' $\ldots$ 치료 길어지 는이 유는?". 의협신문 Doctor's News, 14 April 2020 (in Korean).

61 Kim Tong-Hyung, "500 of Korea's 1,00o Coronavirus Cases Tied to Shincheonji Church", Christianity Today, 25 February 2020. Retrieved 12 August 2020, https://www.christianity today.com/news/2020/february/korea-coronavirus-shincheonji-church-daegu-covid19 .html.

62 Yonhap, "Shincheonji to donate blood plasma of 4,00o members recovered from CoviD-19", The Korea Herald, 23 June 2020. Retrieved 12 August 2020, http://www.korea herald.com/view.php?ud=20200623000906. 
be found and tested. ${ }^{63}$ Lee Jae-myung, the Governor of Gyeonggi Province, and member of the ruling Democratic Party, who led the raid on SCJ headquarters, pronounced that "this is a state of war," with the SCJ clearly identified as the enemy. ${ }^{64}$

On June 22, the City of Daegu filed a lawsuit against the SCJ for damages of 100 billion won on the grounds of allegedly hindering lockdown efforts and causing thousands of additional infections. The compensation demanded is significant, amounting to two-thirds of the coronavirus-related spending of the city. ${ }^{65}$ It may bankrupt the SCJ and threaten its existence. On July 8, at the request of the Prosecutor's Office, Suwon District Court issued a warrant for the arrest of three SCJ officials on charges of obstructing justice and inciting the destruction of evidence. ${ }^{66}$ These individuals were accused of providing health authorities with erroneous information and documentation regarding the number of SCJ followers and the venues of past gatherings. According to reports, the SCJ deleted the personal information of about 100 followers because the latter did not consent to their data being surrendered to the authorities. ${ }^{67}$ Also in July, three further SCJ officials were prosecuted in connection with the list of members and the deletion of details of members who refused to reveal their personal data to the public health authorities. ${ }^{68}$ Thus, providing information about approximately 240,000 members, and excluding a few on the basis of privacy concerns, led to criminal indictment. Note that Korean health authorities requested information not only on the entire SCJ member base in Korea, but also personal information relating to its international members, persons who were in the process of becoming members, as well as SCJ workers.

63 Jun Ji-hye. "Gov't raids Shincheonji headquarters to secure list of follower", The Korea Times, 5 March 2020. Retrieved 12 August 2020, https://www.koreatimes.co.kr/www/ nation/2020/03/119_285669.html.

64 Raphael Rachid. "Being Called a Cult Is One Thing, Being Blamed for an Epidemic Is Quite Another", New York Times, 9 March 2020. Retrieved 12 August 2020, https://www.nytimes .com/2020/03/o9/opinion/coronavirus-south-korea-church.html.

65 Rosie Perper. "A South Korean doomsday church linked to thousands of coronavirus cases is being sued for $\$ 82$ million in damages", Insider, 25 June 2020. Retrieved 12 August 2020, https://www.insider.com/south-korea-doomsday-church-shincheonji-sued-daegu -coronavirus-damages-2020-6.

66 "3 Shincheonji officials arrested for hindering virus control measures", Yonhap News Agency, 21 July 2020. Retrieved 12 August 2020, https://en.yna.co.kr/view/AEN20200708010800325.

67 Ibid.

68 "Sending out 3 additional executives of Shincheonji Daegu Church, who were deliberately missing", Teller Report, 7 July 2020. Retrieved 12 August 2020, https://www.tellerreport .com/tech/2020-07-07-sending-out-3-additional-executives-of-shincheonji-daegu -church--who-were-deliberately-missing.HJ7Q6Edbkv.html. 
The SCJ was not the only Church linked to an increase in COVID-19 infections in Korea. In June, Wangsung Presbyterian Church (WPC) emerged as a new source of infections. The WPC is a small congregation of around 1,700 followers, and therefore attracted less attention. ${ }^{69}$ Other clusters occurred in the Anyang Jesus Younggwang Church, the Ilgok Central Church, the River of Grace Community Church in Seongnam, the Manmim Central Church, and the Gwangneuksa Temple in Gwangju. ${ }^{70}$ In response to these outbreaks, the KCDC recommended a series of preventive measures applicable to all religious facilities, without targeting a particular community. These included contactless methods of holding events, such as online gatherings, disinfecting and ventilating shared spaces, social distancing, and avoiding activities that move respiratory droplets through the air (such as singing, chanting, and shouting). ${ }^{71}$ The KCDC recommended using instrumental music instead of a choir or congregational singing, and avoiding group meals or small group gatherings. ${ }^{72} \mathrm{De}-$ spite the emerging church clusters, the KCDC did not categorize churches as high-risk facilities, alongside nightclubs, bars, and movie theatres. ${ }^{73} \mathrm{But}$ similarly to premises classed as high-risk, since July 2020, churches must require visitors to scan a QR code containing their personal data before entering their premises, and ban any gatherings other than regular worship services. ${ }^{74}$ Churches that do not comply with these measures face temporary closure. ${ }^{75}$ From an epidemiological perspective, the July situation, involving multiple clusters, is far less controllable and potentially more disconcerting than when

69 Yonhap. "S. Korea reports 51 more coronavirus cases amid cluster infections at Seoul church", The Korea Herald, 27 June 2020. Retrieved 12 August 2020, http://www.koreaher ald.com/view.php?ud=20200627000022.

70 Korean Centre for Disease Control. "The updates on Covid-19 in Korea as of 6 July", Retrieved 12 August 2020, https://www.cdc.go.kr/board/board.es?mid=\&bid=0030\&act $=$ view\&list_no $=367718 \&$ tag $=\&$ nPage $=1$.

$71 \quad$ Ibid.

$72 \quad$ Ibid.

73 Chang May Choon. "Coronavirus cluster outbreaks persist despite strict social distancing in South Korea", The Straits Times, 28 June 2020. Retrieved 12 August 2020, https://www .straitstimes.com/asia/east-asia/cluster-outbreaks-persist-despite-strict-social-distanc ing and "Covid: South Korea weighs listing churches as 'high risk", Tribune, 1 July 2020. Retrieved 12 August 2020, https://www.tribuneindia.com/news/world/covid-south-korea -weighs-listing-churches-as-high-risk-107091.

74 Ron Rang. "Govt: Churches Must Follow Key Quarantine Guidelines", TBS eFM News, 8 July 2020 Retrieved 12 August 2020, http://tbs.seoul.kr/eFm/newsView.do?typ_80o=N\&idx $\_800=3395230 \&$ seq_80o $=$.

75 "Tougher Anti-infection Measures Set to be Implemented at Churches", Korea Bizwire, 10 July 2020. Retrieved 12 August 2020, http://koreabizwire.com/tougher-anti-infection-mea sures-set-to-be-implemented-at-churches/164275. 
infections originated in a single cluster (involving the SCJ).${ }^{76}$ But in the second epidemic wave, none of the aforementioned churches experienced a government crackdown similar to the SCJ in the first wave.

No other Protestant church, including those linked to fresh outbreaks, has been targeted with lawsuits or threatened with dissolution, although some of their practices appear prima facie significantly more controversial than those of sCJ, particularly several months into the epidemic. For example, at the Manmin Central Church, one of the largest Protestant congregations in the country, 200 members gathered in early March to prepare video footage for use in services in response to government guidelines for social distancing. ${ }^{77}$ Also in March, at the River of Grace Church in Sungnam City, the wife of its leading pastor sprayed salt water into the mouths of followers in the belief that this would prevent the spread of the virus. ${ }^{78}$ Many other Protestant churches refused to close their doors and move worship online, sparking some public criticism, but nothing more. ${ }^{79}$ While, like the cases linked to the SCJ, it is difficult to definitively verify the precise details, spikes in cases did occur after these practices were reported. Admittedly, some churches, such as the WPC, responded to the outbreaks immediately, following the guidelines on information logging and social distancing, in a way not unlike that of the SCJ. ${ }^{80}$ In July, the Protestant churches found common ground to speak out against the ban on church gatherings. ${ }^{81}$ From an official and societal perspective, however, the blame for the worsening situation should not be seen as falling on one church, or even on all churches. Rather, any large gathering or assembly in a confined space presents a risk, regardless of its nature or location.

76 Lee Hye-in \& Bak Chae-yeong. "Infectious Disease Experts Call for Need to Expand Level-2 Physical Distancing Nationwide", The Kyunghyang Shinmun. Retrieved $12 \mathrm{Au}-$ gust 2020, http://english.khan.co.kr/khan_art_view.html?artid=202007071826097\&code $=710100$.

77 Park Chan-kyong. "Coronavirus cluster emerges at another South Korean church, as others press ahead with Sunday services", South China Morning Post, 30 March 2020. Retrieved 12 August 2020, https://www.scmp.com/week-asia/health-environment/article/3077497/ coronavirus-cluster-emerges-another-south-korean.

78 Ibid.

79 “(2nd LD) Protestant churches under fire for holding Sunday services despite coronavirus epidemic", Yonhap News Agency, 17 March 2020. Retrieved 12 August 2020, https://en.yna .co.kr/view/AEN20200317005952315.

80 "Another church group infection...Have the quarantine guidelines for small groups outside the church become ineffective?", Yonhap News Agency 27 June 2020 Retrieved 12 August 2020, https://www.yna.co.kr/view/AKR20200626163700530.

81 Yonhap. "Protestant community protests government's ban on church gatherings", The Korea Herald, 8 July 2020. Retrieved 12 August 2020, http://www.koreaherald.com/view .php?ud=20200709000331. 
The Korean authorities were widely praised for their response to the COVID-19 outbreak. There is a broad consensus that Korea's response to the MERS outbreak had stood it in good stead for the 2020 novel coronavirus pandemic. It is also true that the legislative reforms of 2015 seem to have served Korea well, endowing the government with far-reaching powers, including means to allocate resources and mobilize a variety of actors in a whole-of-society effort to combat the spread of infectious disease. ${ }^{82}$ Although Korea succeeded in flattening the curve, the international praise that greeted its endeavors belied a lack of scrutiny, including by international legal scholars. Particularly questionable was the positioning of Korea as a poster child of "effective rationalism." Daly distinguished the Korean approach from that of "autocratic opportunist" Hungary, where the parliament "empowered the prime minister to rule by decree, setting no time-limit for the emergency, and arming the government with a law criminalizing 'publication of false or distorted facts." 83 Yet, given the far-reaching powers provided by the relevant Korean legislation, the distinction was not as clear-cut in practice as may seem to have been in theory.

The Korean authorities used Articles 76, 6, and 34(2) to extract surveillance footage, credit card histories, and cellular geolocation data of both confirmed and potential patients, without judicial approval. This enabled the government to rapidly contact-trace hundreds of thousands of citizens as a means of curtailing the spread of the disease. Based on this information, the government sent emergency text messages alerting citizens of nearby cases of coronavirus infection. A government-mandated GPS-tracking app was designed to monitor and punish people who broke quarantine, and frequent government reports listed the location of every single confirmed case. Although the information was generally pseudonymized (as was that of Patient 31), disclosing individuals' age, gender, movements, and the location of testing or treatment rendered many individuals readily identifiable. Subsequent removal of information posted online or elsewhere is effectively irrelevant if the person has been identified in the interim. For example, highly detailed information was

82 Lee, Kyu-Myoung, \& Kyujin Jung. "Factors Influencing the Response to Infectious Diseases: Focusing on the Case of SARS and MERS in South Korea", 16(8) International journal of environmental research and public health (2019), 1432.

83 Tom Daly, "Democracy and the Global Emergency - Shared Experiences, Starkly Uneven Impacts”, (Verfassungsblog, 15 May 2020). 
published on municipal websites, including, at times, individuals' daily schedule, details of their residence, and employer. ${ }^{84}$

The provisions of the IDCPA were employed in a variety of manners that were to prove problematic vis-à-vis SCJ members. The Governor of Gyeonggi Province justified the raid on SCJ headquarters to seize a membership list of the church on the basis of Article 76, obviating the need to procure a warrant, and allowing for a dawn raid on a religious institution without judicial oversight. The raid was explained on the basis of doubts about the veracity of a list of members that the SCJ had previously supplied. According to reports, the prosecution was initially reluctant to carry out searches and seizures at SCJ facilities, but the Minister of Justice urged the prosecution service to proceed with the raids, arguing for vigorous investigations even at the National Assembly. ${ }^{85}$ So did the Mayor of City of Deagu, Kwon Young-jin, although requests for warrants by city police were twice rejected. ${ }^{86}$

The right to know was invoked liberally, with authorities in some cities feeling obligated to share the whereabouts of certain patients to every smartphone in their area by emergency text messages, and with one citizen reportedly receiving more than 900 alerts over four days. According to the $\mathrm{sCJ}$, public officials called certain SCJ members on a daily basis following the submission of the membership list, a measure that, from an epidemiological perspective, was almost certainly unwarranted. The disclosure requirement also permitted private developers to aggregate the data released by the government in its various alerts, to develop mobile applications that warned members of the public if they came within 100 meters of a confirmed patient, an SCJ facility, or potentially contaminated buildings or persons. SCJ facilities were deemed contaminated and thus shut down on the basis of Article 47(1) IDCPA, which provides no criteria for how this is to be determined. ${ }^{87}$ Many SCJ members were identified as potentially infected, which disproportionately affected the SCJ and its membership, with private entities actively contributing to the impression that

84 "Too much information? Privacy questions over South Korea virus details", Today, 10 March 2020. Retrieved 12 August 2020, https://www.todayonline.com/world/too-much -information-privacy-questions-over-south-korea-virus-details.

85 "Official investigation launched into Shincheonji", Korea JoonAng Daily, 5 March 2020. Retrieved 12 August 2020, https://koreajoongangdaily.joins.com/news/article/article.aspx? aid $=3074643$.

$86 \quad$ Ibid.

87 The Korean government invoked these provisions to forcibly shut down nearly $400 \mathrm{SCJ}$ facilities in one province alone, and to ban religious services for at least two weeks. In response, SCJ leaders have complained of "persecution" and a "witch hunt." See Brian Kim, "Lessons for America: How South Korean Authorities Used Law to Fight the Coronavirus", Lawfare, 16 March 2020. 
the Church was, to some extent, responsible for the outbreak, and an active danger to society.

On February 26, the National Assembly enacted three bills that revised the laws on infectious disease, quarantine, and medical services in response to the surge of cases linked to the SCJ. The laws mandated testing and quarantining of individuals likely infected with COVID-19. ${ }^{88}$ Those who refused to be tested faced fines of up to 3 million won. Those who refused to self-quarantine or be hospitalized could face up to a year in prison or a fine of 10 million won. ${ }^{89}$ This provision took effect on April 5, and the first person was imprisoned under new law on May 26. The laws empowered the Minister of Health, city mayors, and provincial governors to conduct fact-finding surveys to ascertain the current conditions of infectious disease management, infection cases, and subsequently announce the results of the surveys. ${ }^{90}$ The Minister for Health has also been empowered to ban the export of face masks, medicines, and sanitary aids, and to ban the entry of foreigners from risk regions. Amending Article 72(2), city mayors, provincial governors, and county and district heads, as well as the Minister of Health, were empowered to request that the police assist with obtaining location information about patients suffering from infectious disease and suspected disease carriers. Last but not least, the revised Medical Services Act strengthened monitoring of patients, families, and medical workers at hospitals with a new digital monitoring system. ${ }^{91}$ Heads of medical institutions or medical personnel who learned of the occurrence of a certain infection within the institution may voluntarily report this to the Minister of Health. This provision will take effect on September 5 .

\section{$5 \quad$ Inconvenient Truths and International Parallels}

Korea was a signatory to seven significant human rights treaties: the International Convention on the Elimination of all Forms Racial Discrimination (ICERD), the Convention on the Elimination of all Forms Discrimination against Women (CEDAW) and its Optional Protocol, the International

88 Law of February 26, 2020. Retrieved 12 August 2020, https://korea.assembly.go.kr:447/res/ tra_read.jsp.

89 "(2nd LD) Bills on disease response pass as parliament reopens after closure due to virus concerns", Yonhap News Agency, 26 February 2020). Retrieved 12 August 2020, https:// en.yna.co.kr/view/AEN20200226003552315.

90 Retrieved 12 August 2020, https://korea.assembly.go.kr:447/res/tra_read.jsp.

91 "Cabinet passes laws to fight Covid-19 outbreak" Retrieved 12 August 2020 http://www .korea.net/NewsFocus/policies/view?articleId=182884. 
Covenant on Civil and Political Rights (ICCPR) and its Optional Protocol, the International Covenant on Economic, Social and Cultural Rights (ICESCR), the Convention on the Rights of the Child (CRC), the Convention against Torture and Other Cruel, Inhuman or Degrading Treatment or Punishment (CAT), and the Convention on the Rights of Persons with Disabilities (CRPD).$^{92}$ The accession of Korea to these treaties reflects its policy on human rights and an effort to undertake progressive modernization following rapid economic development since the 1960s, when its per capita GDP had been below that of Uganda. A substantial revision of the 1948 Constitution, undertaken in 1987, was a turning point for democratization and strengthening of the rule of law, followed by a good deal of domestic human rights legislation. ${ }^{93}$ The updated constitutional text contains multiple articles treating fundamental rights and freedoms. In particular, the right to freedom of religion is laid down in Article 20, which also provides that no state religion shall be recognized, and that Church and state are separate. Discrimination based on a citizen's religious belief is strictly forbidden by Article 11, reflecting the international treaties to which Korea is party. Recent decisions of the Constitutional Court make it clear that this freedom must be respected by public authorities.

At the Ministry of Culture, Sport and Tourism, there is a special Religious Affairs Office with two Religious Affairs Divisions that serve as the primary government contact for religious organizations. ${ }^{94}$ It works with the seven members of the Korea Conference of Religions for Peace, representing Buddhism, Wan-Buddhism, Confucianism, Korean Native Religions, Cheondoism, Protestantism, and Catholicism on issues of interfaith solidarity. ${ }^{95}$ Note, however, that the situation between individual religions is occasionally fractious, that coercive conversion programs continue to exist, and attempts are routinely made by major religions to suppress minor ones. ${ }^{96}$ For example, the SCJ, which converted a good number of its followers from mainstream Christian churches,

92 Whiejin Lee. "The Enforcement of Human Rights Treaties in Korean Courts", 23(95) Asian Yearbook of International Law (2017), 96.

93 Ibid. See also James M. West \& Edward J. Baker. "The Constitutional Reforms in South Korea 1987: Electoral Processes and Judicial Independence", 1 Harvard Human Right Yearbook (1988), 135 .

94 Ministry of Culture, Sports and Tourism, “Organizational Chart”. Retrieved 12 August 2020, https://www.mcst.go.kr/english/ministry/organization/orgChart.jsp.

95 U.S. Department of State. International Religious Freedom Reports. South Korea. Retrieved 12 August 2020, https://www.state.gov/report/custom/52af4ebd57-2/.

96 "Violations of Human Rights in the democratic South Korea", Globe Newswire, 27 November 2019. Retrieved 12 August 2020, https://www.globenewswire.com/news-release/ 2019/11/27/1953088/o/en/Violation-of-human-rights-in-the-democratic-South-Korea .html. 
saw the first cases of "deprogramming" as early as $2003 \cdot{ }^{97}$ The principal target group for deprogramming is young women. According to the report "Coercive Change of Religion in South Korea," published by Human Rights Without Frontiers in March 2020, ${ }^{98}$ between 2003 and 2019, more than 1,500 former SCJ members were forced to resign from work or school, to sign agreements for conversion counselling, or were confined, abducted, physically attacked, forced to divorce, forcibly admitted to a mental health institutions, or suffered from other human rights violations as part of their deprogramming. This adds to the evidence that long before the COVID-19 crisis, members of the SCJ had been subject to discrimination and lost social status, reputation, or employment. These are goods especially valued in the Korean society, embodied in the concept of chemyon. Chemyon, meaning face, is a crucial value in Korean culture, where "one's reputation and social standing rely on his or her ability to save face." Chemyon is, however, not only a property of individuals but also of families and other social groups, presupposing mutual "face-saving." 99

There is no comprehensive anti-discrimination law in Korea, creating something of a lacuna. Currently, there are separate laws of limited effectiveness, covering a variety of discrimination grounds. ${ }^{100}$ Between 2007 and 2020, six proposals for a comprehensive anti-discrimination law were submitted to the National Assembly, but without success. ${ }^{101}$ In October 2019, President Moon called for various religious organizations to support a comprehensive antidiscrimination law that specifically protects against discrimination on religious affiliation and other grounds. ${ }^{102} \mathrm{~A}$ bill was introduced to the freshly elected National Assembly on 29 June, 2020 by the opposition progressive Justice Party. In July, however, rather than proceeding with this bill, the ruling Democratic Party pledged to submit a similar anti-discrimination bill. ${ }^{103}$ The proposal for a

97 Massimo Introvigne. "Shincheonji: An Introduction”. 4(3) The Journal of CESNUR (2020), 7.

98 Human Rights Without Frontiers. "Coercive Change of Religion in South Korea: A Report on The Practice of Kidnapping, Confinement and Forced De-Conversion in South Korea", March 2020.

99 Shim, Theresa Youn-ja, Min-Sun Kim, and Judith N. Martin. Changing Korea: Understanding culture and communication. Vol. 10. Peter Lang, 2008. p. 73 .

1 oo National Human Rights Commission of Korea. "Taking Bold Step Towards Equality for All", 7 July 2020. Retrieved 12 August 2020, https://www.humanrights.go.kr/site/program/ board/basicboard/view?boardtypeid=7003\&boardid=7605641\&menuid=002002001.

101 Jung Da-min. "Anti-discrimination law back on table at National Assembly", The Korea Times, 15 July 2020. Retrieved 12 August 2020, https://www.koreatimes.co.kr/www/na tion/2020/07/113_292216.html.

102 U.S. Department of State. International Religious Freedom Reports. South Korea. Retrieved 12 August 2020, https://www.state.gov/report/custom/52af4ebd57-2/.

103 Amnesty International. "South Korea: New anti-discrimination bill offers hope and safety to many", 16 July 2020. Retrieved 12 August 2020, https://www.amnesty.org/en/latest/ news/2020/07/south-korea-new-anti-discrimination-bill-offers-hope-and-safety/. 
new anti-discrimination law enjoys overwhelming support in the electorate, ${ }^{104}$ but a backlash against the bill came from far-right Christian groups, which obstructed the work of representatives at the National Assembly in charge of processing the bill. ${ }^{105}$ The same groups have hindered discussions on previous legislative proposals, ${ }^{106}$ and have subjected the $\mathrm{SCJ}$ to sustained criticism.

The response to the coviD-19 outbreak has raised questions about how responses to national crises may undermine Korea's position as a state committed to the protection of human rights, including religious freedom. Although it would have been possible to restrict any nexus between the SCJ and COVID-19 to particular events and subsets of the religious community (the Daegu congregation), there has been no discernible effort to do so. On the contrary, there seems to have been an active effort to implicate the entire religious community, at the national, regional, and local levels. The machinery of the state was employed to threaten leaders via the criminal justice system. These drastic measures against the SCJ were taken mostly by two local officials - the Governor of Gyeonggi Province and the Mayor of Seoul, two areas in central Korea that contain more than half the population of the country. The recent criminal prosecutions in the City of Daegu in North Gyeongsang Province and in Suwon in Gyeonggi Province, have resulted in a stifling and oppressive atmosphere for the SCJ and its members.

Korea also witnessed public excesses, albeit on a small scale, against SCJ members. Alleged incidents ranged from verbal abuse, work discrimination, to public shaming and summary dismissal from jobs. There are also reports of hospitals treating SCJ members differently than others, including refusal of treatment. The SCJ also stated that many of its members were ostracized by their families, and two deaths occurred as result of domestic violence following the revelation of affiliation with the Church, as well as a potential suicide. ${ }^{107}$ Personal data leaks may have represented an additional source of human rights violations. In February, a list of some 1,00o SCJ members from the Jeonbuk Province appeared online. Government officials denied any instances

104 "Far-right Christians Hinder Legislation at National Assembly" (Korea Bizwire, July $7^{\text {th }}$ 2020), available at $<$ http://koreabizwire.com/far-right-christians-hinder-legislation-at-na tional-assembly/163987>.

105 Ibid.

106 Jung Da-min. "Anti-discrimination law back on table at National Assembly", The Korea Times, 15 July 2020. Retrieved 12 August 2020, https://www.koreatimes.co.kr/www/na tion/2020/07/113_292216.html.

107 "Shincheonji Member Monitored For Coronavirus Jumped From Her Apartment + Police Currently Investigating", KpopStarz, 11 March 2020. Retrieved 12 August 2020, https:// www.kpopstarz.com/articles/291919/20200311/shincheonji-member-monitored-for-coro navirus-jumped-from-her-apartment-police-currently-investigating.htm. 
of mishandling the information. ${ }^{108}$ Although the SCJ kept track of these incidents on its website, there is no evidence that the authorities made any effort to follow up on them. If these allegations are true, they constitute serious human rights violations, including infringements upon the freedom of religion, as protected by the Korean constitution and international human rights treaties to which Korea is party. At the same time, other individuals, including civil servants not belonging to the SCJ, reportedly suffered negative consequences resulting from a lack of adequate privacy safeguards concerning the COVID-19 outbreak, including false allegations of infidelity, criticism, hate speech, stigmatization, and online bullying. ${ }^{109}$

Still, the crackdown on the SCJ and its supporters is singular and points to a pattern of discrimination. Two days before Patient 31's discharge, on April 26, Seoul Metropolitan Government announced that it would force the dissolution of a legal entity known as HWPL (Heavenly Culture, World Peace, Restoration of Light). HWPL is an international peace advocacy group, which since 2017 has enjoyed special consultative status within the Economic and Social Council of the United Nations (ECOSOC). HWPL is linked to the SCJ: the chairman of HWPL, Lee Man-hee, is also the head of SCJ . HWPL engages in humanitarian and charitable initiatives, and is a rather innocuous body that brings young Koreans into contact with people worldwide to advocate for peace and human rights. The reasons cited for the dissolution included: (a) failing to comply with procedural requirements, such as holding an annual general meeting and conducting an audit; (b) conducting activities that go beyond its stated purpose (support for cultural exchange and for relations with developing countries); and (c) acting in a manner contrary to the public interest. In a press release, the Seoul government announced that "after the CoviD-19 incident, the government has synthesized evidence through a high-intensity administrative investigation, the statements of victims of the SCJ, and media reports over the past four months from February 29. On this basis, it has identified illegal activities." 110 The proposal to dissolve the corporation is presently being disputed in court, and it seems that the Seoul Metropolitan Government had effectively admitted having used material obtained on public health matters

\footnotetext{
108 "Stop witch hunt, says Shincheonji", The Korea Herald, 28 February 2020. Retrieved $12 \mathrm{Au}$ gust 2020, http://www.koreaherald.com/view.php?ud=20200228000778\&mod=skb.

109 "Too much information? Privacy questions over South Korea virus details", (Today, 10 March 2020. Retrieved 12 August 2020 https://www.todayonline.com/world/too -much-information-privacy-questions-over-south-korea-virus-details.

110 Jung Yun-seok, "Cancellation of HWPL corporation... 'Shincheonji will be painful", Kportal News, 24 April 2020. Retrieved 12 August 2020, http://www.kportalnews.co.kr/news/ articleView.html?idxno=20165.
} 
from SCJ sources to collect evidence for the purposes of investigating, and ultimately shutting down a corporate entity run by the leader of the Church.

These two recent incidents are unsettling for several reasons. The action against HWPL, whether warranted or not, appears to rest on evidence obtained for specific purposes, on the basis of an exceptional statute drafted to provide adequate response to a rapidly spreading pandemic. Neither story behooves a state providing proper protection of human rights and observing the rule of law. Several warning signs are apparent. By turning the SCJ into a scapegoat and failing to dispel the perception that it was somehow responsible for importing and spreading the novel coronavirus, the government raised serious questions about human rights protection.

Political Temptation and Legal Flexibility

The CoviD-19 offered the Korean government an additional opportunity to cast members of a small religious community as 'the other', and potentially, as dangerous for society at large. Admittedly, many sCJ members were infected or exposed to the virus, but the proportionality of many of the measures undertaken is suspect. Preventing such abuse in times of crisis should be one of the goals of any system aiming to respect the rule of law and human rights.

Certain human rights treaties to which Korea is party may be subjected to restrictions by state governments, within limits. Some treaties also provide for the more far-reaching option for states to impose derogations from some of their obligations during serious crises. Such derogations may apply to all rights other than so-called non-derogable rights under the ICCPR. Over 20 states have submitted notifications to the United Nations, the Organization of American States, or the Council of Europe concerning unilateral derogations from some of their treaty obligations under the ICCPR (Article 4), and two regional human rights treaties, the ACHR (Article 27) and the ECHR (Article 15). In so doing, they officially declared the outbreak to constitute a state of emergency threatening the life of the nation. The number of derogations due to COVID-19 is completely unprecedented. Other states have resorted to a variety of forms of domestic emergency powers, which tend to involve rule by decree, with the executive assuming additional law-making powers. In many cases, they also provide for some deviation from constitutionally protected fundamental rights. With or without international notification, these steps involve a significant risk of abuse.

The Korean government was neither obligated to issue a notification under the ICCPR, nor to declare an emergency on the basis of domestic law, because 
its domestic legal framework had undergone substantial reform after the 2015 MERS crisis. The government argued that the situation did not meet the requirements of the Korean Constitution for the issuance of an emergency order. ${ }^{111}$ The authorities were equipped to react to CoviD-19 using normally applicable powers and procedures according to the IDCPA, as amended. But although the Korean authorities had devised a legislative framework that allowed the principal purpose of the IDCPA to be achieved, namely curbing the pandemic, its negative side-effects were significant. Our first instinct may be to question whether the legislation in question was fit for the purpose. With the benefit of a hindsight, and six months into the pandemic, it would seem plain that it was not.

The IDCPA was conceived as a means of avoiding the invocation of emergency powers legislation stricto sensu. Nevertheless, it is legislation devised to prospectively address a certain type of emergency, namely crises involving outbreaks of infectious diseases. It is designed to deal with an evolving, potentially uncertain, situation, in which false moves by public authorities may entail grave consequences for the public at large. Thus, such legislation must provide sufficient authority and flexibility to the government to proceed rapidly and effectively with measures needed to curb the spread of the virus. This may explain the lack of concrete definitions of key terms, such as persons "likely to be infected" (Article 76). Each virus evolves differently, and different epidemiological circumstances may necessitate different concrete measures. Similarly, failing to fully define what information the public authorities may seize, and how they may use it, may be excused by the rapid evolution of technology. A similar outbreak would have looked different a decade ago in how people communicate and share information, and how the authorities may use that information. Therefore, a degree of flexibility must be built into definitions concerning categories that are evolving, so that the legislation can be effectively employed when the moment arrives, but not to the point of enabling their abuse.

Allowing the search and seizure of personal data without judicial oversight by issuing a warrant seems an excessive intrusion into the private lives of citizens. This is not the case, however, if such powers are accompanied by sufficient safeguards, including the data minimization principle, storage limitation, integrity and confidentiality, accountability of the data controller, as well as lawfulness, fairness, and transparency - principles succinctly expressed by the European Union General Data Protection Regulation, which represents the

111 Seokmin Lee, "Fighting covid 19 - Legal Powers and Risks: South Korea", Verfassungsblog, 25 March 2020. 
gold standard in this domain. ${ }^{112}$ Moreover, an effective system of data protection oversight and judicial review must be available to injured citizens.

This is not the first occasion on which Korea has displayed a complicated relationship between its desire for surveillance in the name of a legitimate interest on the one hand, and human rights obligations on the other. In its concluding observations to the 4th reporting cycle under the ICCPR, in 2015, the Committee noted with concern that Korean law allowed for subscriber information to be requested from any telecommunications operator without a warrant for investigative purposes. It was equally concerned with the practice of identifying demonstrators by means of mobile phones and wiretapping by the National Intelligence Service. ${ }^{113}$ Ahead of the overdue 5 th state report to the Committee, Korea should indicate any legal measures taken to ensure that surveillance, including for the purposes of state security, is compatible with the ICCPR. ${ }^{114}$ The National Human Rights Commission noted that according to a recent decision of the Constitutional Court, neither the interception of cables by the National Intelligence Service, nor the execution of searches without a warrant, conformed to the Constitution. The Court found a violation of the proportionality principle that clearly indicated that the current state of privacy laws, including the Protection of Communication Secrets Act, insufficiently protected the rights of individuals. ${ }^{115}$

Parallels may be drawn between the above cases and the employment of powers under the IDCPA to collect information concerning the SCJ. The proportionality of actions by national, provincial, regional and municipal, actors against the SCJ must be assessed in light of the factual situation. First, the SCJ is not responsible for the entire epidemiological situation in Korea. The epidemiological situation is highly volatile, and although the SCJ was, according to the KCDC, linked to approximately $60 \%$ of initial infections, in late July, it had been linked with around $35 \%$ of cases, and relatively few new cases, indicating that the Church had cooperated in bringing the virus under control. Second, even for SCJ members, there were other ways to become infected apart from

112 Article 5 of Regulation (EU) 2016/679 of the European Parliament and of the Council of 27 April 2016 on the protection of natural persons with regard to the processing of personal data and on the free movement of such data, and repealing Directive 95/46/EC.

113 Human Rights Committee. Concluding observations on the fourth periodic report of the Republic of Korea. 3 December 2015. Paragraphs 42 and 43.

114 Human Rights Committee. List of issues prior to submission of the fifth periodic report of the Republic of Korea. August 21, 2019. Para 20.

115 National Human Rights Commission of Korea Information to the UN Human Rights Committee for the adoption of the List of Issues Prior to Reporting in relation to the consideration of the Fifth Periodic Report by the Government of Republic of Korea. Para 18. 
church service or SCJ contacts. Even where no preventive measures are taken, epidemiological studies estimate that each infection generally results in approximately four new infections. ${ }^{116}$ Therefore, it was not justified for a few dozen initial cases to lead to tracing hundreds of thousands SCJ followers, including some outside Korea. Third, the SCJ could legitimately demand the observance of certain standards in the handling of the data of SCJ members by health authorities, notably where the legislative framework did not provide sufficient guarantees for data protection. Fourth, legislation adopted in February 2020 in response to the evolving situation may have provided better, more nuanced, and less intrusive means of stopping the spread of the virus. All these circumstances should have been taken into consideration in the application of the proportionality principle, which the Korean authorities failed to do.

Dealing with any emergency involves compromises. Officially declaring a state of emergency and notifying international institutions about derogations from certain human rights treaty obligations may serve as a means of taming emergency powers by making states justify measures taken on the basis of necessity, proportionality, exigency in the situation, temporality, and a commitment to human rights. Framing the situation as being within the bounds of normalcy, allows using regular legislation and avoids the suspension of democratic institutions or rule by decree. As shown by the IDCPA model, the flexibility needed to make such a model effective may still result in abuses because pandemics are likely to require exceptional measures and some deviation from full enjoyment of all human rights by all citizens. It would be prudent, therefore, to introduce these measures through a framework that entails a commitment to legality and to the full restoration a normal state of affairs in the shortest possible time. The efficiency of the IDCPA in combating the spread of the virus becomes a relevant factor in assessing the legitimacy of any infringements to human rights that occurred during its 2020 invocation.

The consequences of the official action concerning the SCJ and its membership were stark. The US Commission on International Religious Freedom denounced the action as an attempt to destroy a religious minority by using the

116 Ying Liu et al. "The reproductive number of COVID-19 is higher compared to SARS coronavirus", 27(3) Journal of Travel Medicine (2020), taaao21. 
pretext of the pandemic. ${ }^{117}$ Many religious groups in Korea dislike the SCJ and deem its views heretical. But as Raphael Rashid noted, "being called a cult is one thing, and being blamed for starting an epidemic is quite another."118 Yet, politicians, officials, and private entities came close to equating the two. The novel coronavirus crisis provided an opportunity for Korean leaders to demonstrate their competence. Has the pandemic and the legislation crafted in the aftermath of the 2015 MERS outbreak created a convenient opportunity for authorities to turn a small religious community into a scapegoat to deflect attention from their failings? It will be crucial to observe whether any of the aforementioned practices find their way into the upcoming UN observations concerning Korea's compliance with the ICCPR.

Comparatively, the Korean authorities have been remarkably successful in bringing the COVID-19 virus under control. Many important lessons were learned from the 2015 MERS outbreak, which enabled the creation of an efficient system, albeit one that made too many compromises with regard to human rights. The lessons learned from the 2020 pandemic should involve improvements in the IDCPA to rein in the arbitrary use of powers and to ensure a greater level of judicial oversight in their employment. The lives saved by the IDCPA provisions constituted a fitting legacy of the victims of MERS. Similarly, if individuals of faith and religious groups are spared abuse and scapegoating when Korea is next affected by a pandemic, it will mean that important lessons have also been learned from the mistakes made in responding to COVID-19.

117 Scott Weiner, Kirsten Lavery, \& Dominic Nard. "The Global Response to the Coronavirus: Impact on Religious Practice and Religious Freedom", United States Commission on International Religious Freedom, March 2020. Retrieved 12 August 2020, https://www.uscirf .gov/sites/default/files/2020\%2oFactsheet\%2oCovid-19\%2oand\%2oFoRB.pdf.

118 Raphael Rachid. Being Called a Cult Is One Thing, Being Blamed for an Epidemic Is Quite Another, New York Times, 9 March 2020. 